\title{
Elena Pulcini. The Time to Think of the Good
}

\section{Elena Pulcini. Il tempo di pensare al Bene}

\author{
Debora SPINI \\ New York University in Florence \\ deb.spini@gmail.com
}

\begin{abstract}
The essay explores the work of Elena Pulcini, who was snatched away by the pandemic when her ideas and her work were becoming more and more visible in the public sphere. Books like Care of the World, or her last work Tra cura e giusti$z i a$, were read and discussed beyond the usual academic circles. Although she was profoundly alien from spectacularisation of any kind, in the last years her profile had become that of a public intellectual whose philosophical work was a point of reference for a wide variety of groups and networks, from feminists to environmentalists.
\end{abstract}

Keywords: Elena Pulcini, Care of the World, passions, subject.

Riassunto. Il saggio presenta la figura di Elena Pulcini, scomparsa nella pandemia quando le sue idee e il suo lavoro stavano diventando più visibili nella sfera pubblica. Libri come La cura del mondo, o il suo ultimo lavoro Tra cura e giustizia sono infatti letti e discussi al di fuori dei soliti circoli accademici. Sebbene profondamente estranea a qualsiasi tipo di spettacolarizzazione, negli ultimi anni il suo profilo era diventato quello di una intellettuale pubblica il cui lavoro filosofico era un punto di riferimento per unampia varietà di gruppi e reti, dalle femministe agli ambientalisti.

Parole chiave: Elena Pulcini, La cura del mondo, passioni, soggetto. 
The pandemic snatched away Elena Pulcini when her ideas and her work were becoming more and more visible in the public sphere. Books like Care of the World, ${ }^{1}$ or even more, her last work Tra cura e giustizia, ${ }^{2}$ were read and discussed beyond the usual academic circles. Although she was profoundly alien from spectacularisation of any kind, in the last years her profile had become that of a public intellectual whose philosophical work was a point of reference for a wide variety of groups and networks, from feminists to environmentalists. The wide diffusion of her ideas did not imply any slackening of scholarly rigour; her works appealed to a wider public because they reflected her authentic, deep commitment.

Pulcini wrote about care because she genuinely did care. She cared about the future of the planet, about humanity's chances of survival, about the very possibility of sharing a world in common. Pulcini did not only comprehend or articulate, but felt how our world was threatened by an impending catastrophe. She was profoundly convinced that doing anything that was in her power to avert it was her personal responsibility, or even more her compelling duty. This conviction led her to take up very concrete political commitments; however, she saw her philosophical work, which she conceived as a Beruf, in the richer meaning of the word, essentially as a form of engagement.

"Saving the world" was for Pulcini an imperative dictated by healthy realism rather than wishful thinking. Whilst her approach was firmly rooted in the tradition of critical theory, and even more in that of social philosophy meant as the critique of social pathologies, ${ }^{3}$ she became more and more aware that, in the present circumstances, thinking of alternatives was a challenge that should not be declined. In one of her last public appearances, she declared that, after decades spent exploring contradictions and pathologies, she had come to the conclusion that "è tempo di pensare al bene"; the time had come for her to think about what could be "the Good", even about what a "good life" could be like. These words were uttered with a smile, and were meant to be a sort of intellectual provocation; yet, they fit quite well with her most basic philosophical perspective, which moved from the critical genealogy of the present to open up towards a normative horizon. She herself defined this approach as heretic normativism (normativismo eretico or normativismo debole). ${ }^{4}$

\footnotetext{
${ }^{1}$ Pulcini, Care of World.

${ }^{2}$ Pulcini, Tra cura e giustizia.

${ }^{3}$ Pulcini was among the founders and coordinators of the Seminario di Teoria critica e Filosofia sociale, which was instrumental in introducing the social philosophy approach. See Calloni, Ferrara, Petrucciani, Pensare la società.

${ }^{4}$ Pulcini, "Generosi perché felici," 13-24.
} 
Her production pursued throughout the years a consistent philosophical program, centred around the theme of the Self, its pathologies as well as its chances and resources. Her quest became all the more relevant when the processes of globalization, already at work for a long time, began to advance at an ever faster pace. The acceleration of the environmental crisis gave her reflection an unprecedented character of urgency. The focus of her work thus broadened from the critique of the modern individual to the search for emotional and cognitive resources which could motivate individuals and collectives to mobilise for the care of the world, and moved on to explore the potential of reflexively and critically cultivated passions.

The analysis of passions has indeed been the fil rouge of her scholarly production for at least the last two decades; its roots can be found even in earlier works, such as Amour passion e amore coniugale. ${ }^{5}$ Although this line of research may seem to lead her outside the field of politics and into that of ethics, Pulcini's identity remains that of a social, but even more specifically of a political philosopher. The philosophical quest for the individual, the self, and the passional universe was not an escape from politics, as much as a way to approach the very core of political agency, that of the cognitive and emotional motivations. Her philosophical itinerary thus evolved in between the two poles of critical engagement with the social, political and anthropological morphology of the present and that of the exploration of the microcosm of individuality. In this journey Pulcini conversed with an extremely wide range of interlocutors and vocabularies, often going beyond the boundaries of academic disciplines; her writing thus acquired a rare, not to say unique, capacity of resonating with its reader at a much deeper level than argumentative reasoning. This contribution does not have any claim of giving justice to the richness and complexity of Pulcini's thought. In fact it will be limited to singling out a few characteristic themes, in view of stressing her identity as a political philosopher.

\section{Pulcini as a philosopher of globalization}

Pulcini was among the first who saw the need for a philosophical interpretation of globalization processes, and doubtlessly she was among the most original. ${ }^{6}$ At the turn of the century, political theory scholarship was intent on exploring the new post-national constellation, concentrating

\footnotetext{
${ }^{5}$ Pulcini, Amour passion e amore coniugale.

${ }^{6}$ The collective book Filosofie della Globalizzazione, which she edited with Dimitri D'Andrea, testifies to her ground-breaking philosophical approach to globalisation. This book originated from the years-long experience of a series of research groups - beginning with La democrazia nelletà della globalizzazione - coordinated by Furio Cerutti.
} 
on canonical themes such as institutional architectures, legitimacy and sovereignty, or the transformations of political actors. Her research widened the lens of observation by choosing as its privileged point of view the transformation of the anthropological paradigm induced by the internal developments of modernity, which resulted in the processes of globalization. This work was done in constant dialogue with other disciplinary fields, from sociology to international relations to psychology. Throughout works such as Individual without Passions and Care of the World she retraced the many transformations of the modern individual to shed light on the itinerary of the appearance of a new form of selfhood, which Pulcini defined as the global Self (io globale), whose pathologies she explored. Most importantly, she understood at a very early stage that the global condition was to be assumed as the overall framework for any reflection on selfhood and individuality and, conversely, that no reflection on the future of politics in the age of globalization could ignore the transformations of individuality.

Pulcini sees in the rise of globalization the result of processes which, although completely internal to modernity, transform the facies of the modern condition so as to make it unrecognizable. This transformation is summed up in large measure by the transition from danger to risk, and subsequently to specifically global risks. The great promise of modernity was to tame and control nature through scientific and technological developments; modern political institutions, beginning with the State, also motivated their claim to legitimacy by their capacity of providing security. Pulcini carefully reconstructed the backfiring mechanism of modern rationality, which, instead of ensuring the reduction of dangers, ended up unleashing a series of inertial processes which jeopardised the very survival of the planet. In close dialogue with Anders, Pulcini identified the "Promethean gap", the imbalance between scientific and technological developments and the human capacity of control, as a major step towards the global Self.?

More generally, she saw in the advent of global risks the unprecedented condition whereby the disappearance of the planet and of all forms of human life within it became a concrete possibility. Her attention was concentrated upon the blatant contradiction between an indisputable "fact" that the dynamics of the global age (again, the rise of global risks) constituted humanity as a community of destiny, and the equally evident incapacity to come up with adequate solutions. Pulcini captured the profound ambivalence of the globalized world, polarised between a generalised loss of boundaries, both geographical and identitarian, and a growing inclina-

${ }^{7}$ Pulcini, Care of World, 95 and ff.; Anders, Antiquiertheit des Menschen. 
tion to political fragmentation and re-entrenchment into political communities obsessed by the fear of anything and anyone beyond their borders (in her language, endogamic communities). She explored the correspondence between these macrophenomena and the ambivalent morphology of the global Self; this thorough genealogical work provided the breeding ground for the normative perspective sketched in works such as Care for the World and even more in Tra cura e giustizia. Her philosophical wager, which would take a more and more definite shape throughout her work, consisted in looking for whatever opportunities and chances might still be open, searching for, so to say, the hidden folds of globalization. As will be better articulated below, in the awareness of the condition of shared vulnerability and mutual dependence brought about by globalization, she would see a powerful last call to action, the last opportunity of mobilizing emotional and cognitive resources in view of a collective praxis for transformation.

\section{Modern Selves - in the plural}

Pulcini's genealogical work on the modern Self went beyond mainstream representations, characterised by traits such as rationality, sovereignty and independence, to explore its constitutive ambivalence. Within the rich fresco sketched by Pulcini, three main steps leading to the full affirmation of the global Self should at least be mentioned: Hobbes' individual, the homo oeconomicus of early capitalism, and finally Tocqueville's homo democraticus.

The Hobbesian individual summarises many of the contradictions of modernity which Pulcini sought to explore. In her view, on the one hand, he ${ }^{8}$ showcases all the typical traits of a Promethean individual, yet his complex morphology contains in nuce elements that somehow herald future developments, insofar as he "realizes the full drama of his state of necessity, deficiency and uncertainty which imposes a self-preserving movement upon him". The Hobbesian individual is aware of his own fragility, and at the same time is also curious and far-sighted, dedicated to the never-ending effort of "protecting himself from the evils he fears, and to obtain the advantages he desires". This model of the individual, it should be noted, has his own set of passions, beginning with a passion for gain and, perhaps more importantly, a passion for the self - both of which are, for Pulcini, "expressions of a deficient and self-preserving individual who attempts to make up for his insufficiency both by obtaining recogni-

\footnotetext{
${ }^{8}$ The choice of the masculine pronoun is intentional, for reasons which will become evident in the next section.
} 
tion for his value and superiority at any cost through the endless pursuits of material goods."

The second passage is the homo oeconomicus. Singled out by Pulcini as the main paradigm in modernity, this model experiences deficiency and need to an even higher degree than his Hobbesian predecessor. Mandeville is the author that accompanies Pulcini in her reconstruction of how the passion for the Self generates a host of acquisitive passions, as ever increasing opulence pushes men towards "a constant and boundless multiplication and complication of their desires." ${ }^{10}$ Adam Smith becomes her main reference point in observing how the same selfish and acquisitive passions, in particular self love, may end up creating a sort of virtuous circle, as the desire to be appreciated, esteemed, and even liked and loved, pushes men to enter into relation with each other. In this perspective, "self love is an eminently relational passion."11 Furthermore, it must be balanced by the universally shared inclination to sympathy, and corrected by the virtue of prudence. Although she did not subscribe to a stereotypical view of the invisible hand, Pulcini captures here a side of the homo oeconomicus that will become crucial for the self-absolutory trait of capitalism: the trust in the free interplay of passion to create a sort of virtuous circle resulting in the common advantage.

With Bataille and Elias, Pulcini ${ }^{12}$ sees modernity as aiming at fully controlling passions; the final result, the "individual without passions", seems to confirm the diagnosis, although the itinerary leading to this anaesthetic condition is far from linear. Pulcini follows the development leading from the Promethean to a narcissistic Self leading up to homo democraticus, whom she identifies as the crux of the contradictions of modernity, ${ }^{13}$ embodying the crisis of the individual as a result of individualism itself. The dialogue with Tocqueville provides her with a point of observation of a series of pathological developments that will reach full completion in the global age. Hobbes' anxious Prometheus evolved, with Smith, into a tranquil and prudent man; democracy induces a further anthropological mutation producing an emotionally weak and apathetic individual. Democratic equality places the individual "before an excess of possibility", whose paradoxical result is to trigger a profound anxiety. "Where everything is possible and everything is virtually available, the fear arises of not grasping the best occasion, not exploiting the most rapid and effective means to satisfy one's needs, not accessing the

\footnotetext{
${ }^{9}$ Pulcini, Individual without Passions, 37.

${ }^{10}$ Pulcini, Individual without Passions, 51, italics in the original.

${ }^{11}$ Pulcini, Individual without Passions, 58.

${ }^{12}$ Bataille, Notion of Expenditure; Elias, Civilizing Process; Pulcini, Individual without Passions, 21.

${ }^{13}$ Pulcini, Individual without Passions, 158.
} 
many perspectives of gratification and pleasure." ${ }^{14}$ The democratic individual is constantly gripped by the fear of "missing out" on something and tormented by the doubt that he may have less than his fellow men. The crisis of the modern individual thus originates "in the paradoxical coexistence of opposing and complementary aspects: solitude and conformism, self realization and loss of identity, omnipotence and weakness, unlimited freedom and the birth of more invisible and totalitarian forms of control." ${ }^{15}$ Prometheus is no longer curious or far-sighted; on the contrary, the homo democraticus is constantly absorbed in himself, a prisoner of a form of mediocre individualism: ${ }^{16}$ democracy does not only break all bonds, but also induces men to "withdraw into their private realm" thus causing a gradual decadence of public life.

These characters pave the way for the postmodern Self and its quintessential manifestation, the global Self. Pulcini identifies the aversion towards the notion of limits as a common and marked trait of these final avatars. Both the Hobbesian Prometheus and the Smithian, or even the Mandevillian, homo oeconomicus had a notion of limit; the first one in order to avoid conflict, the second in order to fit into societies' fabric. ${ }^{17}$ In both cases, this compromise came with a very high price to pay in terms of self-inflicted "amputations", in Pulcini's words, to the potentially unlimited expansion of acquisitive passions. As she considered the quest for authenticity as a major chance opened by modernity, she does acknowledge and appreciate a similar aspiration in the postmodern Self, and, in the footsteps of Marcuse, she does sympathise with the reaction against this sacrificial aspect of modernity. However, she remains focused on the pathologies and, with Lipovetsky, identifies narcissism as the last shore of homo aequalis. ${ }^{18}$ Pulcini unravels one of the most paradoxical aspects of the postmodern self, which will be further amplified by the context of the global age: the growing inability to pursue individual autonomy, one of the greatest promises of modernity. The loss of limits leads to the progressive slackening of social bonds; motivated by an obsessive quest for individual self-realization, this loss of relationality "seriously undermines his [the global Self's] very own sovereignty: meant both

\footnotetext{
${ }^{14}$ Pulcini, Individual without Passions, 110.

${ }^{15}$ Pulcini, Individual without Passions, 130.

${ }^{16}$ Pulcini, Individual without Passions, 11, italics in the original.

17 "In short, domination and loss of sense, renunciation, alienation and atomism: these seem to be the most evident signs of the degeneration of the self-repressive and disciplinary model of early modernity. This presupposes a unilateral subject, that is, a subject who is indeed capable of building strategies to place a limit on unlimitedness, but who ends up paying a high price, especially in emotional terms, for his acquisitive and instrumental calling" (Pulcini, Care of World, 23).

${ }^{18}$ Lipovetski, Ėre du vide.
} 
as the Promethean ability to recognize and pursue his interest and as the enhancement of the Self and his most authentic desires and ideals."19

This complex heritage contributes to the birth to the global Self, the crossing point between a series of late or postmodern figures of individuality, the spectator-individual, the consumer Self and, last but not least, Anders' homo creator. With Anders, Pulcini describes this ultimate version of Prometheus as "he who reacts to his feeling of inadequacy and rebels against the inevitability of his human limits; he who puts his physical limits to the test, sounding out his body's most extreme possibilities and endurance thresholds to the point of producing that 'second nature' which today is no longer just a metaphor, but a real and disturbing reality produced by the technologies of human engineering." ${ }^{20}$ The generalised process of the loss of boundaries (from territories to identity), which she identified as a marked feature of the global condition, also results in a loss of limits; this combination generates the paradoxical coexistence of the Self's insecurity, disorientation, loss of certainties and points of reference, and at the same time, his longing for the limitless expansion of his possibilities, expectations and desires. The global Self is thus left to float between hybris and insecurity; evidently, modernity's promises have not been honoured, and homo oeconomicus is nothing more than "a residual myth of liberal ideology." ${ }^{21}$ The passion that was such a protagonist of modernity - fear - is also the most profoundly affected by the anthropological mutations induced by globalization. The Hobbesian nexus between fear and reason, or fear and self-preservation, ${ }^{22}$ is, in a context marked by the emergence of global risks, irreparably damaged. Pulcini explored how the healthy, productive fear of modernity is replaced in the global age by a twofold mechanism. The global Self is entrenched within a mechanism of denial of the actual magnitude of risks, made possible by the separation between knowing and feeling, matched by a corresponding disproportionate and persecutory fear of the Other. ${ }^{23}$

\footnotetext{
${ }^{19}$ Pulcini, Care of World, 28.

${ }^{20}$ Pulcini, Care of World, 37. In earlier writings Pulcini connected the expansion of desire to the opening of limitless possibilities offered by technology, which makes unimaginable achievements appear within reach (Pulcini, Potere di Unire, 172). Pulcini also engaged with the theme of the post-human. Whilst she warned against the possible Promethean drift of an uncritical euphoria, she did not endorse an equally uncritical naturalistic humanism. Her distinctive position was that of embracing hybridity as a marked feature of the Self, as well as identifying responsibility as an alternative to heteronormativity. "Dall'Homo faber," 15-18.

${ }^{21}$ Pulcini, Care of World, 19.

${ }^{22}$ Pulcini, Care of World, 88.

${ }^{23}$ Pulcini, Care of World, 112.
} 


\section{Female selves}

This critical itinerary within the hegemonic parable of modern subjectivity and its pathologies did not lead Pulcini towards deconstructing the very notion of Self, as in her opinion this move jeopardised the "concrete and irreplaceable singularity of the Self," ${ }^{4}$ the necessary breeding ground for responsibility. Pulcini remained true to her vocation and philosophical project of exploring alternative paths, first of all by stressing the internal dialogue taking place within individual authors and also by suggesting alternative itineraries within modernity itself. The dialogue with Rousseau constitutes a crucial landmark, as Pulcini turns to him in search of passions such as pitié and philia, important elements to define a Self open to otherness and capable of care. At this point, a however scant analysis of her work as a feminist philosopher can no longer be deferred, as the lens of gender was actually constitutive of her philosophical research rather than an appendix or a side interest.

Her reflection on gender difference is profoundly entwined with her reflection on care and vulnerability as resources for the global age, as a never interrupted thread connects her early writings on Amour conjugal to her most recent theoretical work about care for the world. Pulcini explores the universe of women's historical experience in a quest for alternative resources to a modern Self, which, in its various avatars, from Hobbes to Smith, is evidently masculine or, more precisely, characterised by a series of traits invariably associated with masculinity, such as rational domination over the passional elements, independence and self-government. Pulcini observed how on the one hand women were constantly associated with vulnerability and dependence, whilst on the other represented as "naturally" oriented to care for the Other. She also gave adequate attention to the process whereby the dimension of the body was increasingly repressed and marginalised throughout modernity, and she recognised the need to give voice to its "memory." ${ }^{25}$ The complexity of the relationship between the feminine Self and the universe of passions in modernity was not lost on her; her work on conjugal love demonstrated how the exclusion of women from rationality implied rather than free access to the universe of passions, the confinement into the more tranquil area of sentiment.

The encounter with Rousseau is of great importance, as his Julie epitomises exactly those features that will prove to be vital resources for Pulcini's normative proposal. By nature, the lady of Clarens inclines towards "care, philia, and love", yet the exercise of these characteristics is strictly

\footnotetext{
${ }^{24}$ Pulcini, Potere di Unire, xv, translation mine.

${ }^{25}$ Pulcini, Potere di Unire, 156.
} 
limited to the private sphere, where Julie's existence is entirely confined because of her sex. ${ }^{26}$ Pulcini's analysis gives full justice to the complexity of Rousseau's views of the female self, as his woman is indeed different, rather than simply defective as in most of Western political literature. At the same time, she highlighted how this caring, loving self is defined by a "nature" that would not admit of any other possibility. Care and philia thus are not a choice, as the feminine self is caged within renunciation and sacrifice. This construction of the female subject is not unique to Clarens, but is to be replicated throughout modernity which constantly excluded women from its major developments. Pulcini is well aware of how women remained mostly peripheral to the Promethean itinerary and, to a certain extent, even from the most recent narcissistic trend exactly because of their being confined to the relational dimension (in relazione). ${ }^{27}$ Pulcini's goal was not to simply translate women's difference from the sphere of privacy to that of politics, and even less to present the female Self as per se antithetic to the pathologies of modernity. This move avoided all the unquestioned assumptions about women's "nature", as her goal was to transform this destiny into a reflexive, critical choice. Actually, Pulcini was well aware of the challenges facing the female Self, which, in the rightful vindication of individual autonomy, is exposed to the temptation of uncritically replicating the masculine Self and experiencing the same unlimited expansion of desire. Pulcini thus explored the complex field of modernity's established "division of labour", which destined women to love and men to desire; and she warned against the risk of falling into the trap of mimetism and conformism. The "passion for the Other", which is indeed one of the most hopeful traits of the female Self, should not be taken for granted, but is the result of a thorough critical work. ${ }^{28}$ In general, for Pulcini women are not endowed with any immediate salvific power because of their "difference". The feminine Self does constitute an alternative within the horizon of modernity because of its historical experience, which, in order to become a expendable resource, has to be reclaimed from its original heteronormativity and transformed into an autonomous, reflexive choice.

To conclude, it is important to observe how Pulcini's thought had no inclination towards essentialism of any kind. Her subsequent reflection on vulnerability and care will also reproduce the same pattern: from destiny to choice.

\footnotetext{
${ }^{26}$ Pulcini, Individual without Passions, 90.

${ }^{27}$ Pulcini, Potere di Unire, 157-163.

${ }^{28}$ Pulcini, Potere di Unire, 134-136.
} 


\section{Vulnerability and care - beyond responsibility}

As mentioned above, Pulcini's diagnostic work was purposefully oriented to find all possible alternative resources and viable chances nesting even in the most entangled knot of contradictions in the global age. This quest brought her to engage more and more with the notion of vulnerability, finding important reference points in an extremely wide selection of interlocutors, going from Jonas to the philosophers of intersubjectivity, in particular Lévinas. However, she was not totally satisfied either by Jonas' responsibility ${ }^{29}$ - which she found flawed because of its strictly deontological foundation - nor Levinas' philosophy of alterity because of its a priori ontological foundation. ${ }^{30}$ Her interest had focused at a very early stage on the anthropological and psychic foundation of the concept of responsibility, ${ }^{31}$ and on elaborating a framework of reciprocity so as to avoid mere deontology (doverismo). Under this point of view her lifelong frequentation with the MAUSS ${ }^{32}$ provided Pulcini with an important tool, in the paradigm of Gift, which she had already singled out in Individual without Passions for its bond-creating potential. Pulcini's reflection on Gift and her genealogical work crossed paths and mutually fertilised each other, as the latter gave relevance to aspects of the self, such as vulnerability, neediness and dependence, constantly kept in the background by mainstream narratives of modernity. Already present in Care of the World, this set of categories was taken up in her last work, Tra cura $e$ giustizia, and given such a crucial role as to become the central feature of humanity itself.

Consistent with her overall philosophical perspective, in Pulcini's view vulnerability does not have any naturalistic character, although it is most definitely a datum. Pulcini is not interested in "vulnerable subjects" as a separate category, to be considered per se "better" than others, as much as she is in vulnerability as a universally shared condition, common to all human beings. ${ }^{33}$ Only the reflexive re-elaboration of the experience

\footnotetext{
${ }^{29}$ Jonas, Imperative of Responsibility.

${ }^{30}$ Levinas, Otherwise than Being.

${ }^{31}$ Pulcini, Individuo senza passioni.

${ }^{32}$ Pulcini promoted and subscribed both Convivialist Manifestos promoted by the Mouvement Anti-Utilitariste dans les Sciences Sociales. See her introduction to the Italian translation of the Second Convivialist Manifesto: Towards a Post Neo-Liberal World (Pulcini, "Prefazione").

${ }^{33}$ The gender perspective is once again an important component of Pulcini's reflection on vulnerability. Given their historical background, women may and must have a special role in "bringing back the memory" of dependence, vulnerability and neediness as a constitutive experience of being in a relationship with Otherness (Pulcini, Tra cura e giustizia, 158). However, this remembrance does not automatically translate into a chance for change, unless it submits to a critical perspective. The same considerations apply also to her reflection on the
} 
of vulnerability enables individuals to empathise, and consequently to care, for each other. The capacity of giving stems exactly from the experience of being vulnerable and needy. The awareness of shared vulnerability thus becomes an important step on the way to finding motivations for engaging in relationships of care, contemplating both asymmetry and reciprocity, and avoiding the pitfalls of a merely voluntaristic foundation of care. The experience of human vulnerability, furthermore, opens a much wider horizon as it permits the individual Self to resonate ${ }^{34}$ with the overall condition of the planet, as it "brings home" the urgency and drama of the environmental crisis.

Always present in Pulcini's work, the theme of care takes up a very distinctive feature in the framework of the global condition, as it transcends interpersonal relationships to embrace the whole "world" - the planet and the whole of human interactions within it. Pulcini conducted a detailed analysis of the possible meanings of the term, identifying three main kinds of care: private, social and global care (affettiva, sociale $e$ globale). Again, Pulcini's emphasis on care does not prioritise a naturalist or essentialist foundation, but instead pays constant attention to the social and even the political context. For this reason, she engaged in the deep and acute work of deconstructing the stark opposition between care and justice, in a close conversation with the main voices of the debate on the ethics of care. The historical experience of women, once again, provides her with an important testing ground in exploring this nexus, as it reveals how the capacity to care and the claims for justice, far from being mutually exclusive, cannot subsist without each other. In order to be real factors of political and social transformation, relationships of care have to stem from an authentic individual and collective motivation, which can hardly be expected to materialise unless individual autonomy is adequately protected. Pulcini also confuted another well-rooted commonplace - the identification of care with emotions and passions, and of justice with disincarnated rationality - by applying a two-fold strategy. On the one hand, she highlighted the emotional aspect of any form of commitment to justice; on the other, she demonstrated how the reference to neediness and vulnerability is an essential component of any claim for justice. ${ }^{35}$ Pulcini thus does not only rescue care from a naturalist and essentialist foundation, as briefly outlined above, but refuses a simplistic identification with the sphere of sentiments, a necessary step to provide a solid motivational

paradigm of gift, which she channelled in her contribution to an important issue of the Revue du MAUSS, Que donnent les femmes?, 49-66.

${ }^{34}$ Pulcini uses this term in the same sense as Hartmut Rosa (Rosa, Resonances).

${ }^{35}$ Pulcini, Care of World, part IV. In articulating the nexus between care and justice, Pulcini engaged in an intense dialogue with Nussbaum's capability approach. 
foundation for global care. This particular form of care is in fact all the more urgent as well as especially challenging, as it requires to care for those who are far away in space and for those who are far in time, such as the future generations. ${ }^{36}$ This last kind of care presents a special challenge: whilst the view of suffering may trigger an emotional drive towards care for those distant in space, the concern for future generations in fact has a distinctive moral element. Pulcini thus affirms the need for a culture of care, which may sustain individual self-binding choices and transform them into concrete, active commitments to preserve the world as a planet. ${ }^{37}$ This passage is particularly important, as Pulcini's ethics of care opens up to open up to the perspective of critiques of forms of life, elaborated by Rahel Jaeggi and other voices from the tradition of critical theory. ${ }^{38}$ In this perspective, Pulcini sees in the care for future generations the point of departure for an immanent critique of the dominant form of life - the hegemony of economic rationality and of capitalist accumulation that proved to be incapable of maintaining its promises. This task evidently cannot be accomplished by turning to the anthropological paradigm of modernity, whose signs of exhaustion have become evident; the passion for the Self, either in its Hobbesian and/or in Smith's acquisitive version, can no longer be trusted to provide a relevant viable solution.

\section{Passions as a resource for care}

When self-interest does not work anymore and when responsibility is not enough, a new set of tools - such as the passion for the other or the passion for justice - becomes necessary, as well as the attempt at revitalising passions which are already present in the arsenal of modernity. Pulcini's exploration of passions as a resource for politics evolves into the quest for a Self capable of developing a passion for justice, for care, and in general for the Other: ${ }^{39}$ the antidote to the paralysing imbalance between knowing and feeling which she identified as one of the most typical, and poisonous, features of the global Self.

The few elements of her intellectual journey sketched above, although far from giving full justice to the complexity of her argumentation, should suffice to show how her philosophical proposal goes much deeper than a generic call to "passions" and "sentiments". In fact, she did not expect

\footnotetext{
${ }^{36}$ Pulcini, Tra cura e giustizia, 72.

${ }^{37}$ Pulcini, Tra cura e giustizia, 138-139.

${ }^{38}$ Jaeggi, Forms of Life.

${ }^{39}$ Pulcini, Tra cura e giustizia, 65.
} 
political, social and cultural changes to arise out of the right set of "feelings", not even empathy, which, while so important for her reflection, is not immediately and automatically conducive to morality.

The theory of passions elaborated in Care of the World and in Tra cura e giustizia places special importance on the relation of mutual influence connecting the passional and emotional sphere to society and even to the political domain, allowing for a "reflexive construction of the subject" in the context of a relational dynamic of sympathy. ${ }^{40}$ Passions and emotions are not eternal and a-historical, but shaped and moulded by normative horizons: the typical example is indignation, as political values do determine when and why behaviours or situations are perceived as offensive. Nor are passions all "good" or "bad" in themselves: some of them are indeed constitutively sterile, as in the case of envy, ${ }^{41}$ whilst others may either trigger empowering transformations, or consolidate or even worsen social pathologies. To make a concrete reference, Pulcini placed great hope in a fruitful revitalising of a "healthy" fear as a propellant for urgent political actions, and showed how a misled passion for justice, not critically evaluated and groomed, may turn destructive, as the most recent political developments demonstrated. ${ }^{42}$

Passions may lead to care - but they need to be taken care of. The final message of Tra cura e giustizia is thus a strong call for a paideia of passions, a theme whose distant origins could be found even in her work on conjugal love. ${ }^{43}$ Passions could and should be cultivated although never manipulated; ${ }^{44}$ in particular, Pulcini was well aware of the capacity of late modern capitalism to mould individuals into the self reproducing mechanism of desire and consumption..$^{45}$ Intersubjectivity and openness to alterity play here a pivotal role. The interaction with the Other, a constant thread of Pulcini's work, is the key to avoiding both the dead end of the mere reaffirmation of modern subjectivity as well as the fallacy of naïve voluntarism: "the Other forces me to cultivate, or even better, to take care of my emotions, in a way that is all the more compelling as it is involuntary." ${ }^{.66}$ More importantly, the encounter with the Other maintains a character of unexpectedness and unpredictability, which differenti-

\footnotetext{
${ }^{40}$ Pulcini, Tra cura e giustizia, 27, translation mine.

${ }^{41}$ Pulcini, Invidia.

${ }^{42}$ Ibid., 64-65.

${ }^{43}$ Pulcini, Amour passion e amore coniugale.

${ }^{44}$ Pulcini, Invidia, 147.

${ }^{45}$ This particular theme was quite present in the work of the Seminario di Filosofia Sociale, which she co- founded and coordinated together with Dimitri D'Andrea, Enrico Donaggio and Gabriella Turnaturi, and whose collective reflection culminated in the volume Felicità Italiane. ${ }^{46}$ Pulcini, Tra cura e giustizia, 167, translation mine.
} 
ates Pulcini's proposal from an ascetic paradigm such as the one adopted, although with significant variations, by Anders, Sloterdijk and Foucault. ${ }^{47}$ The passion for the Other does indeed have a root in the "genetic background" of the modern Self, as highlighted by her genealogical work; yet it also needs to be the object of a purposeful effort to avoid the dangers intrinsic to modernity itself, so as to strengthen the emotional dimension that recognises the Other not as a source of fear, but as an intrinsic, constitutive dimension of the Self. ${ }^{48}$

\section{Where do we go from here}

Elena Pulcini left us a rich heritage, and set some demanding tasks for us. Although Covid-19 put a sudden halt to her philosophical journey, her thought continues to open new directions of research. Her genealogical work not only provides an enlightening point of view for many open philosophical and political conversations, but it finds an immediate application in many current, and urgent, debates taking place way beyond the sphere of scholarship. To give but a few examples, her reflection on the emotional and passional genealogy of endogamic communitarianism is an important tool for analysing the rise of neo-authoritarian, ethnocentric parties and regimes. This specific brand of regressive utopias cannot be understood outside of an analytic frame which combines the focus on the socio-economic aspects of globalization and their impact on political institution with a different kind of genealogy, which concentrates on the anthropological transformations.

Pulcini's dialogue with feminist political thought still has much to offer. Her anti-essentialist, anti-naturalist interpretation of feminine selfhood as the result of reflexive choices could be a way out of many stalemates, beginning with the stark and paralysing view of those who reify "difference" to the temptations of an uncritical mimetism towards the male subject. Her contribution to overcoming this opposition would be valuable in revitalising the potential of feminism as a critical point of view on the social pathologies of late capitalism.

The most urgent task however concerns the core of her philosophical project and of her heretic normative perspective, the possible implementation of her appeal for a paideia of passions. An important question arises at this point: whether politics in the wider sense may constitute a space

\footnotetext{
${ }^{47}$ Pulcini, Tra cura e giustizia, 160-161; Anders, Antiquiertheit des Menschen; Bataille, Notion of Expenditure; Foucault, Technologies of Self; Sloterdijk, On Anthropotechnics.

${ }^{48}$ Pulcini, Potere di Unire, 157.
} 
where passions can - or even better, must - be cultivated in dialogue with reflexively formulated normative perspectives.

The final pages of Tra cura e giustizia give some hints of Pulcini's own expectations and hopes. Needless to say, global civil society, where grassroots movements such as Fridays for Future practice Arendt's vision of politics as azione orizzontale di concerto, caught Pulcini's attention. In this galaxy of movements and networks Pulcini could detect the first stirrings of a different model of Individual, seeking meaning rather than gain. ${ }^{49}$ She also had high expectations for educational institutions and artistic practices; more generally, she looked for all possible means to revitalise the ethical imagination which helps everyone to feel close to those who are distant in time and space, and for all possible means of creating a passional breeding ground for global care. In this general framework, references to the exquisitely "institutional" sphere of politics are not as frequent as might be expected. Although she followed Nussbaum in appreciating the exemplarity of great politicians, ${ }^{50}$ Pulcini draws quite pessimistic conclusions about political institutions and actors, ${ }^{51}$ and does not dedicate the best of her attention to alternative institutional architectures to the dominant market-driven manifestations of global governance. These silences are questions in themselves, leaving an important part of her theory in a sort of non finito. Her overall legacy - the commitment to the "care of the world" - and her groundbreaking reflection on passions, vulnerability and care make the task of talking about "politics" - political spaces, actors, and institutions - no longer deferrable, as a quick recapitulation of some of the points discussed above may illustrate. Pulcini has offered a unique contribution by indicating how passions are a card to play in the effort of stopping, or at least slowing down, the impending catastrophe exactly by showing how they are not destined to remain a burst of unarticulated emotionality, but, on the contrary how they can be shaped and oriented by reflexive value choices. She also identified vulnerability as a potentially universal common ground, where humanity could become aware of itself as a community of destiny rather than the sole province of specific categories. She likewise disentangled care and gift from a possible sacrificial drift, by indicating their strong connection with justice.

The dialogue between passions and values evidently requires lively public spheres; vulnerability as a major resource for political agency and non-sacrificial care also presuppose a framework where individual rights, meant in their broader sense of "capabilities", must be adequately guaran-

\footnotetext{
${ }^{49}$ Pulcini explored this point in her chapter in Felicità Italiane.

${ }^{50}$ Nussbaum, "Capabilities and Human Rights."

${ }^{51}$ Pulcini, Tra cura e giustizia, 177.
} 
teed. The same applies, perhaps to an even stronger degree, to her innovative intuition of the potential of care as a form of life capable of immanent critique. The context marked by the processes of globalization, which she so masterfully explored, has demonstrated beyond any reasonable objection how the forms, actors, practices and even the vocabulary and imaginary inherited from Western modernity are blunt weapons, and how the unprecedented challenges of the global age call for a major innovative effort. The gently provocative affirmation - è tempo di pensare al bene does not contradict, but rather confirms, the urgent needs for new institutional architectures to provide some kind of political governance to the processes of globalization.

Elena Pulcini was an original as well as a consistent, coherent thinker, yet she was not interested in constructing a "system", hence why she could not be expected to walk every possible road and to cover every possible topic. She was also very clear about her priorities, and she purposefully focused her work on the universe of subjectivity because she saw it as absolutely necessary in view of any reflection on political agency. Her thought is rich and fertile exactly because it remains open: open to further elaborations, open to accept new sets of questions and challenges, open to experiment with new fields of inquiry. The task of threading further paths is a challenge that awaits being taken up by all those whom she helped to think, to reflect, but even more, all those whom she supported in the difficult exercise of feeling the need to mobilise for a common salvation. $\grave{E}$ tempo di pensare al bene - a difficult task indeed, but the best way to honour her legacy.

\section{References}

Works by Elena Pulcini:

Amour passion e amore coniugale: Rosseau e le origini di un conflitto moderno. Milano: Marsilio, 1990.

L'individuo senza passioni. Individualismo moderno e perdita del legame sociale. Torino: Bollati Boringhieri, 2001.

"Il Sé mimetico e il falso riconoscimento." In Marina Calloni, Alessandro Ferrara e Stefano Petrucciani, eds. Pensare la società, L'idea di una Filosofia Sociale. 105-125, Roma: Carocci 2001.

Il Potere di Unire. Femminile, desiderio, cura. Torino: Bollati Boringhieri, 2003.

Umano, post-umano. Potere, sapere, etica nelletà globale. Edited with M. Fimiani and V. Gessa Kurotschka. Roma: Editori Riuniti, 2004. 
"Dall'homo faber all'homo creator: scenari del post-umano." In Ignazio Sanna, ed. La sfida del post-umano. Verso nuovi modelli di esistenza? 15-18. Roma: Studium, 2005.

Invidia. La passione triste. Bologna: Il Mulino, 2011.

The Individual without Passions. Modern Individualism and the Loss of Social Bonds.London: Lexington Books, 2012.

"Donner le care." Revue du MAUSS 2012/1, no. 39 (2012), Que donnent les femmes?: 49-66. https://doi.org/10.3917/rdm.039.0049

Care of the World. Fear, Responsibility and Justice in the Global Age. New York: Springer, 2013.

"La sfida del post umano e la nostra responsabilità." Parolechiave 1, January-June (2014): 187-200. https://doi.org/10.7377/77682

"Filosofia sociale: critica del presente e prospettive per il futuro." Politica $e$ società, 3 (2016): 299-324. https://doi.org/10.4476/85511

"Generosi perché felici o felici perché generosi." In Dimitri D’Andrea, Enrico Donaggio, Elena Pulcini e Gabriella Turnaturi, Felicità Italiane. Un campionario filosofico, Bologna: il Mulino: 13-24.

Tra cura e giustizia. Le passioni come risorsa sociale. Torino: Bollati Boringhieri, 2020.

“Prefazione." In Internazionale convivialista, L'Arte di vivere insieme. Per unalternativa al neo liberismo. Secondo Manifesto convivialista. Milano: Feltrinelli, 2020.

\section{Other works}

Anders, Günther. Die Antiquiertheit des Menschen. Beck: Munich 1956.

Bataille, Georges. The Notion of Expenditure, in Visions of Excess. Edited by A. Stoeckl. Minneapolis: University of Minneapolis Press 1985.

Elias, Norbert. The Civilizing Process: The History of Manners. New York: Urizen Books, 1978.

Foucault, Michel. Technologies of the Self. A Seminar with M. Foucault. Amherst: University of Massachusetts Press, 1988.

Jaeggi, Rahel. Critique of Forms of Life. Boston: Harvard University Press, 2013.

Jonas, Hans. The Imperative of Responsibility, In Search of an Ethics for the Technological Age. Chicago: The University of Chicago Press, 1984.

Levinas, Emmanuel. Otherwise than Being or Beyond Essence. Pittsburgh: Duquesne University, 1998.

Lipovetski, Gilles. L'ère du vide: Essais sur l'individualisme contemporain. Paris: Gallimard, 1983.

Nussbaum, Martha. "Capabilities and Human Rights." Fordham Law Review, Vol. 6, 22 (1997): 273-291. 
Nussbaum, Martha. Political Emotions. Why Love Matters for Justice. Boston Mass.: Harvard University Press, 2013.

Rosa, Hartmut. Resonances. A Sociology of our Relationship with the World. Oxford: Polity Press 2018.

Sloterdijk, Peter. You Must Change Your Life: On Anthropotechnics. Oxford: Polity Press 2013. 